\title{
Public Support and Terrorism: The Putin Paradox
}

\author{
João Ricardo Faria*
}

Nottingham Business School, Nottingham Trent University, NG1 4BU, UK

\begin{abstract}
The increase in the number of terrorist attacks in Russia suggests that anti-terrorist policies have failed to solve the Chechen terrorist problem. The Putin paradox, named after Russia's president Vladimir Putin, is the capacity of the incumbent government to maintain or even increase its popular support while suffering increasing terrorist attacks. This paper presents a dynamic model where government's public support is related to terrorist attacks and counter-terrorism activities, and it shows that the Putin paradox is one of the possible steady state solutions of the model. In the Putin paradox case the equilibrium level of government's public support is positively impacted by the equilibrium number of terrorist attacks.
\end{abstract}

\section{INTRODUCTION}

Russia's president Valdimir Putin has claimed that the Chechen conflict is virtually over and that his strategy of no negotiations with pro-independence Chechen leaders has worked. He has used the word "normalization" to define the status of Chechnya. However, no matter how he defines Chechnya's conflict, the fact is that Chechen terrorist attacks in Russia have increased over the years (Council on Foreign Relations, 2004). For instance, in October 2002 Chechen gunmen seized a Moscow's theatre and 129 theatregoers died as a result of the battle between Russia's counterterrorist forces and the gunmen. More recently, in August 2004 two passenger planes were destroyed by Chechen suicide bombers, killing 89 people, and in early September 2004, more than 330 children and adults died in the Beslan school siege three days after Chechen rebels took over the school during a ceremony to mark the start of the academic year ${ }^{1}$.

The hostage taking incidents, particularly the takeover of a Moscow's theatre and the Beslan school, are of special interest since from the terrorists perspective hostage taking incidents are among the most dangerous missions. In Mickolus et al. (2006) hostage events comprise $15 \%$ of all terrorist events in the world for a sample period of 1968-2005. Terrorists resort to such attacks because they can result in high payoffs in terms of publicity, recruitment ${ }^{2}$ and ransoms. According to Sandler et al. (1983) terrorists choose to engage in attacks perceived to be less risky among a given menu of choices. For instance, among hostage taking categories, kidnappings are the less risky, followed by skyjackings,

*Address correspondence to this author at the Nottingham Business School, Nottingham Trent University, NG1 4BU, UK; Tel: +44(0) 115848 2762; Fax: +44(0) 115848 4707; E-mail: joao.faria@ntu.ac.uk

I would like to thank, without implicating, two referees for valuable comments.

${ }^{1}$ The Chechen terrorist attacks in Russia can be qualified as transnational terrorism. Recent studies on the casualties time series of transnational terrorism (e.g. Enders and Sandler, 2005) suggest that when terrorism is in a low-intensity regime with attacks below a data-determined threshold, shocks that raise the level of events are sustainable, while for high-intensity regime shocks are episodic with series returning rapidly to the mean number of events (see also Enders and Sandler, 2000 and 2002).

${ }^{2}$ Bueno de Mesquita (2005) analyzes a model where governmental counterterrorism can generate a negative externality by fomenting terrorist support. while the takeover of buildings with hostages is riskier (Brandt and Sandler, 2008). This is why the strategy of the Chechen terrorists in the takeover of buildings with hostages is so interesting.

These attacks appear to be related to a new breed of radical Islamist Chechens who have eclipsed the more moderate pro-independence fighters who formed the core of the rebel movement during the wars in the 1990's (de Waal, 2004).

One possible way for Putin to fight this type of terrorists is by gaining the support of moderate representatives of the Chechen separatists, who reject extreme Islam, and enter into negotiations that can produce a settlement while preserving Russia's territorial integrity (Cohen, 2003). The problem, however, is that Moscow's policies have excluded these Chechens from any possible solution. Instead, Putin has relied on harsh counter-terrorist policies, increasing repression on Chechens ${ }^{3}$, trying to crush Chechen resistance.

The increase in the number of terrorist attacks suggests that the anti-terrorist policies put forward by Putin's government have failed in solving Chechnya's problem. Despite this, Putin has managed to keep his public support ${ }^{4}$. This is what we call the Putin paradox. In the Putin paradox there is a positive feedback mechanism between terrorist attacks and public support for the government's apparent failed counterterrorist policies.

Brandt and Sandler (2008) find that violent ends or deaths are associated with more hostage incidents. In the case of Russia, both takeovers of buildings with hostages by the Chechens terrorists ended up with great loss of innocent hostage lives after law enforcement agents stormed the buildings. This created a negative publicity for the terrorist's

\footnotetext{
${ }^{3}$ As The Economist (2004a) reports "The carte blanche given to Russian security forces to abduct, torture and kill young Chechen men suspected of rebel ties spawned the "black widow" phenomenon". The black widow phenomenon describes the terrorist attacks carried out by Chechen women, many of them have lost family members in the conflict between Chechens and Russians.

${ }^{4}$ On this regard we quote The Economist (2004b) "In 1999, Mr Putin, then prime minister, sent them back in (Russian Federal troops to crush Chechnya's separatists) Early the next year, he swept to victory in the presidential election after promising there would be no compromise with the rebels. Since then the terrorist attacks on civilians across Russia have only worsened and the rebels have continued to inflict losses on federal forces in Chechnya. Nevertheless, Mr. Putin's tough policy has remained popular among Russians, and earlier this year he was re-elected by a landslide".
} 
cause, and may have cost its public support. Here lies one possible explanation for the Putin Paradox. Terrorists by becoming riskier and brutal lose public support for their cause, and the questionable success of government antiterror policies seems to be excusable before such a foe.

This paper presents a simple dynamic model that relates public support, terrorist attacks and counter-terrorism activities. In the model public support varies along time negatively with terrorist attacks, which triggers and increases government's anti-terrorist actions that fuel new terrorist attacks. One of the possible steady state solutions of the model is that the equilibrium level of government's public support is positively impacted by the equilibrium number of terrorist attacks, which is precisely the Putin paradox.

\section{THE MODEL}

Public support $(P)$ is the main variable determining incumbent government's reelection. Let us assume an upper bound $\bar{P}$ and a lower bound $\underline{P}$ for public support, where $\bar{P}>\underline{P}$. The lower bound gives the minimum necessary public support for reelection. Public support varies along time, $d P / d t \equiv \dot{P}$, as a decreasing function of terrorist attacks $(T)$ :

$\dot{P}=\bar{P}-f(T)-\Omega$

Where $f(T) \geq 0$ for $T \geq 0$, and $f$ is an increasing function of terrorist attacks $(T), f_{T}(T)>0$, and $\Omega \geq 0$ is a parameter that captures the exogenous forces that affect government's public support. We have $\bar{P} \geq \Omega$ so $[\bar{P}-\Omega$ ] gives the amount of public support that incumbent government enjoys at a given point of time and that can be eroded by terrorist attacks 5

We assume that terrorists react positively to government's counter-terrorist activities $(A)^{6}$. This means that the number of terrorist attacks increase with government's antiterrorist policies

$\dot{T}=h(A)-\delta T$

Where $\delta$ is the rate of depreciation of terrorist attacks [which may involve suicide attacks]. We assume that function $h$ is an increasing function of counter-terrorist activities, $h_{A}>0$.

The government puts forth counter-terrorism activities that aim at answering immediately any terrorist attack in order to increase its public support:

$\dot{A}=g(P, T)-c A-\Psi$

Where $c$ is the unitary cost of anti-terrorist actions, and $\Psi>0$ is a parameter that captures the exogenous forces that affect government's implementation of anti-terrorist policies,

\footnotetext{
${ }^{5}$ Siqueira and Sandler (2006) present a model involving terrorists, elected policymakers, and voters. However they study anti-terror policies by two countries, confronted by the same transnational terrorist threat.

${ }^{6}$ For a game-theoretic analysis of counter-terrorist policies see Arce and Sandler (2004) and Sandler and Arce (2007).
}

such as opposition parties, civil liberties, new anti-terror technologies ${ }^{7}$, etc. We assume function $g$ is an increasing function of $P$ and $T, g_{P}>0, g_{T}>0$.

It is important to stress that according to equations (2) and (3) terrorist attacks and counter-terrorist activities affect each other positively in dynamic terms, which can be interpreted as a tit-for-tat strategy for both sides. That is, when terrorists attack the government immediately reacts and viceversa which brings about an escalation of the conflict.

In order to assess the relationship between popular support, terrorism and counter-terrorism we need to solve the model using explicit functions. For the sake of mathematical simplification, let us assume linear functions such as:

$h(A)=\alpha A ; f(T)=a T ; g(P, T)=\beta P+b T$

where $a, b, \alpha$ and $\beta$ are positive parameters. The interpretation of these parameters are straightforward: $\alpha$ stands for the marginal impact of government's counter-terrorist actions on the time variation of terrorist attacks, that is $d \dot{T} / d A=\alpha$; $\beta$ is the marginal impact of public support on the time variation of counter-terrorist activities, $d \dot{A} / d P=\beta ; a$ captures the absolute value of the marginal impact of terrorist attacks on the time variation of public support which is given by:

$d \dot{P} / d T=-a$; finally $b$ is the marginal impact of terrorist attacks on the time variation of counter-terrorist activities, $d \dot{A} / d T=b$.

Using the linear functions defined above we can rewrite equations (1)-(3) as :

$\dot{P}=\bar{P}-a T-\Omega$

$\dot{T}=\alpha A-\delta T$

$\dot{A}=\beta P+b T-c A-\Psi$

The steady state solutions of this dynamic model are:

$\dot{P}=0 \Rightarrow T^{*}=a^{-1}[\bar{P}-\Omega]$

$\dot{T}=0 \Rightarrow A^{*}=\frac{\delta}{\alpha} T^{*} \Rightarrow A^{*}=\frac{\delta}{a \alpha}[\bar{P}-\Omega]$

$\dot{A}=0 \Rightarrow P^{*}=\frac{c}{\beta} A^{*}-\frac{b}{\beta} T^{*}+\frac{\Psi}{\beta} \Rightarrow P^{*}=\left[\frac{c \delta}{\alpha \beta}-\frac{b}{\beta}\right] T^{*}+\frac{\Psi}{\beta} \Rightarrow$

$P^{*}=\left[\frac{c \delta}{\alpha \beta}-\frac{b}{\beta}\right] a^{-1}[\bar{P}-\Omega]+\frac{\Psi}{\beta}$

Notice that the model is block recursive. Therefore each endogenous variable is determined in a sequential manner. Equation (4) determines the equilibrium steady state value of the number of terrorist attacks, $T^{*}$, and then it follows by equation (5) the determination of the equilibrium value of

\footnotetext{
${ }^{7}$ On anti-terrorist technologies see Faria (2006).
} 
anti-terrorism activities, $A^{*}$, and then equation (6) determines the equilibrium value of public support, $P^{*}$.

By equation (4) the equilibrium number of terrorist attacks, $T^{*}$, depends on the amount of public support that the incumbent government enjoys at a given point of time that can be eroded by terrorist attacks $[\bar{P}-\Omega]^{8}$. The greater this difference the greater $T^{*}$. By equation (5) there is a direct relationship between the equilibrium number of terrorist attacks, $T^{*}$, and the equilibrium value of anti-terrorism activities, $A^{*}$, which implies that an increase in the equilibrium amount of terrorist attacks leads to a proportional increase in counter-terrorist activities. The government overreacts to terrorist attacks if $\delta>\alpha$. By the same token, equation (6) shows that there can be a positive relationship between the equilibrium number of terrorist attacks, $T^{*}$, and the equilibrium level of public support, $P^{*}$, which yields the most important result of this paper, the Putin paradox.

\section{THE PUTIN PARADOX}

The Putin paradox is the capacity of the incumbent government to keep or even increase its popular support while suffering terrorist attacks. It can be seen in equation (6) for the case where there is a positive feedback between the equilibrium number of terrorist attacks $T^{*}$ and the equilibrium level of government's public support $P^{*}$, provided that $\bar{P}>\Omega$ :

$\frac{d P^{*}}{d T *}=\frac{c \delta}{\alpha \beta}-\frac{b}{\beta}>0$, if $\frac{\delta}{\alpha}>\frac{b}{c}$

In order to understand the Putin paradox, note that the equilibrium level of public support, $P^{*}$, is affected directly and indirectly by the equilibrium number of terrorist attacks, $T^{*}$. The direct impact of terrorist attacks on public support for the government is negative and is given by the term: $[-b / \beta]$. The indirect impact is positive and is given by the term $[c \delta / \alpha \beta]$. The indirect impact operates through increases in counter-terrorist activities as responses to terrorist attacks. When the indirect impact is greater than the direct impact we have the Putin paradox.

The Putin paradox is more likely to occur in a situation where the government overreacts to terrorist attacks, $\delta>\alpha$, and/or the unitary cost of anti-terrorist activities $c$ is greater than $b$, the marginal impact of terrorist attacks on the time variation of counter-terrorist activities, that is: $\frac{\delta}{\alpha}>1>\frac{b}{c}$.

\section{DISCUSSION}

The analysis of the Putin Paradox provides interesting insights, and may help explain the political decisions and performance of president Putin, or, for that matter, any incumbent government of a country under increasing terrorist attacks.

\footnotetext{
${ }^{8}$ In Faria and Arce (2005) terrorism maybe pervasive and permanent if the number of hard-core terrorists is large enough to offset deterrence
}

The Putin paradox provides valuable information for the incumbent government on what really matters in terms of reelection in a country under increasing terrorist attacks. In order to be reelected, an incumbent government needs to obtain an equilibrium level of public support, $P^{*}$, that lies in the interval $P \leq P^{*} \leq \bar{P}$, where the minimum requirement for reelection is $P * \geq \underline{P}$. According to the Putin Paradox an incumbent government has to set counter-terrorist actions and costs given by $\alpha$ and $\mathrm{c}$, respectively, at such level that:

$$
\begin{aligned}
& P *=\left[\frac{c \delta}{\alpha \beta}-\frac{b}{\beta}\right] a^{-1}[\bar{P}-\Omega]+\frac{\Psi}{\beta} \geq \underline{P} \Leftrightarrow \\
& \frac{c}{\alpha} \geq \frac{b}{\delta}+\frac{a[\beta \underline{P}-\Psi]}{\delta[\bar{P}-\Omega]}
\end{aligned}
$$

The above expression (8) for $c / \alpha$ provides interesting guidelines for the incumbent government's reelection strategies because it indicates that the rate $c / \alpha$ should increase in proportion with $P, \beta, \Omega$ and $b$ and should decrease with $\delta, \Psi$ and $\bar{P}$.

Regarding the above parameters, two of them are of particular interest: $\Omega$ and $\Psi . \Omega$ is a parameter that captures exogenous forces that affect government's public support. Among these forces are: The relative success of government's economic policies, overall economic outlook of the country, etc. For instance, in the case of Russia, high oil prices have brought a much better economic prospect than in the previous decade, which suggests $\Omega$ is increasing. Higher $\Omega$ makes it easier for Putin administration to spend more in counter-terror, c, for a given level of anti-terror measures, $\alpha$. Concerning parameter $\Psi$, it captures exogenous forces that affect government's implementation of anti-terrorist policies, such as the role of opposition parties, the press, civil liberties, etc. In the case of Russia, it is well-known that Putin has put in place a political structure that limits freedom of opposition parties and the press, which reduces $\Psi$. A reduction in $\Psi$ is consistent with a reduction of the righthand side of the term in inequality (8) for a given level of $c / \alpha$, facilitating his reelection and electoral success.

Therefore the combination of high oil prices and low political freedom helps explain Putin's success and, as a consequence, the Putin paradox.

\section{CONCLUDING REMARKS}

The Putin paradox is defined as the capacity of a government under systematic and increasing terrorist attacks to keep or even increase its popular support. It is a paradox because the increase in the number of terrorist attacks suggests that anti-terrorist policies have failed in solving the terrorist problem.

This paper examines a dynamic model formed by a system of three differential equations that describes the time variation of public support, terrorist attacks and counterterrorism activities. The Putin paradox is one of the possible steady state equilibrium of this model. In the Putin paradox there is a positive feedback between the equilibrium number 
of terrorist attacks and the equilibrium level of public support. The Putin paradox occurs when the indirect [and positive] effect of terrorist attacks on government's public support, which operates through the increase in counter-terrorist activities driven by the government's reaction to terrorist attacks, is greater than the direct [and negative] effect of terrorist attacks on government's public support.

The model sheds lights on the political decisions and performance of president Putin and offers insights for electoral success of any incumbent government of a country under increasing terrorist attacks.

\section{REFERENCES}

Arce, D., \& Sandler, T. (2004). Counterterrorism: A game-theoretic analysis. Journal of Conflict Resolution, 49, 183-200.

Brandt, Patrick, T., \& Sandler, T. (2008). Hostage taking: Understanding terrorism event dynamics. Journal of Policy Modeling, forthcoming.

Bueno de Mesquita, E. (2005). The quality of terror. American Journal of Political Science, 49, 515-530.

Cohen, A. (2003). Chechnya, terrorism and U.S. security interest. Retrieved May 2, 2005, from http://www.inthenationalinterest.com/Articles/ Vol2Issue1/Vol2Issue1Cohen.html

Council on Foreign Relations. (2004). Chechnya-based terrorists. Retrieved May 2, 2005, from http://cfrterrorism.org/groups/chechens.html.

De Wall, T. (2004). Analysis: Putin's permanent problem. BBC News World Edition, Retrieved May 2, 2005, from http://news.bbc.co.uk/ 1/hi/world/europe/3617782.stm.
Enders, W. \& Sandler, T. (2000). Is transnational terrorism becoming more threatening. Journal of Conflict Resolution, 44, 307-332.

Enders, W. \& Sandler, T. (2002). Patterns of transnational terrorism, 19701999: Alternative time series estimates. International Studies Quarterly, 46, 145-165.

Enders, W., \& Sandler, T. (2005). Transnational terrorism 1968-2000: Thresholds, persistence, and forecasts. Southern Economic Journal, 71, 467-482.

Faria, J. R. (2006). Terrorist innovations and anti-terrorist policies. Terrorism and Political Violence, 18, 47-56.

Faria, J. R., \& Arce, D. (2005). Terror support and recruitment. Defence and Peace Economics, 16, 263-273.

Mickolus, E. F., Sandler, T., Murdock, J. M., \& Fleming, P. (2006). International Terrorism: Attributes of Terrorist Events, 1968-2005 (ITERATE 5). Dunn Loring, VA: Vinyad Software.

Sandler, T., Tschirhart, J., \& Cauley, J. (1983). A theoretical analysis of transnational terrorism. American Political Science Review, 77, 3654.

Sandler, T., \& Arce, D. (2007). Terrorism: A game-theoretic approach. In T. Sandler, \& K. Hartley (Eds.), Handbook of Defense Economics, Vol. 2, (pp.775-813). Amsterdam: Elsevier.

Siqueira, K. \& Sandler, T. (2006). Terrorist backlash, terrorism prevention, and policy delegation. Unpublished manuscript, University of Texas at Dallas.

The Economist. (2004a). Putin points the finger in the wrong direction. Retrieved May 2, 2005, from http://www.economist.com/agenda/ displayStory.cfm?story_id=3150096.

The Economist Global Agenda. (2004b). Victims of a conflict without end. Retrieved May 2, 2005, from http://www.economist.com/agenda/ displayStory.cfm?story_id=3170269 